\title{
PENGARUH DAYA TARIK PROMOSI, KEMUDAHAN PENGGUNAAN, DAN KEAMANAN TERHADAP MINAT PENGGUNAAN E-MONEY PADA MAHASISWA POLITEKNIK NEGERI SEMARANG
}

\author{
CYNTHIA SYERIN PERDANA PUTRI* \\ JATI HANDAYANI \\ TRIBEKTI MARYANTO AGUSTINUS \\ Politeknik Negeri Semarang \\ *cynthiasyerin@gmail.com
}

\begin{abstract}
The purpose of this study is to analyze the effect of promotional attractiveness, user-friendliness, and security on the interest in using e-money either simultaneously or partially in Semarang State Polytechnic students. The population of this study were all Semarang State Polytechnic students. The sample selection method used convenience sampling with 100 respondents in this study. The data were analyzed using multiple linear regression with the help of SPSS 25. The results of this study indicate that simultaneously or partially promotional attractiveness, ease of use, and security have a significant effect on interest in using electronic money among Semarang State Polytechnic students. It shows that promotions are carried out to attract students, ease of use and security attract users to switch to e-money especially in the digital era.
\end{abstract}

Keywords. Promotions Attractiveness, User Friendliness, Security, Interest in Using E-Money

Abstract. Tujuan penelitian ini adalah untuk menganalisis pengaruh daya tarik promosi, keramahan pengguna, dan keamanan terhadap minat menggunakan e-money baik secara simultan maupun parsial pada mahasiswa Politeknik Negeri Semarang. Populasi penelitian ini adalah seluruh mahasiswa Politeknik Negeri Semarang. Metode pemilihan sampel menggunakan convenience sampling dengan 100 responden dalam penelitian ini. Analisis data menggunakan regresi linier berganda dengan bantuan program SPSS 25. Hasil penelitian ini menunjukkan bahwa secara simultan atau parsial daya tarik promosi, kemudahan penggunaan, dan keamanan berpengaruh signifikan terhadap minat penggunaan uang elektronik pada mahasiswa Politeknik Negeri Semarang. Hal tersebut menunjukkan bahwa promosi yang dilakukan untuk menarik minat pelajar, kemudahan penggunaan dan keamanan menarik pengguna untuk beralih ke e-money khususnya di era digital.

Keywords: Daya Tarik Promosi, Keramahan Pengguna, Keamanan, Minat Menggunakan E-Money

\section{PENDAHULUAN}

Perkembangan teknologi yang semakin maju dan modern menyebabkan kebutuhan primer manusia semakin meningkat. Hal ini menunjukkan bahwa manusia membutuhkan uang untuk memenuhi kebutuhan tersebut. Banyaknya aktivitas yang harus dilakukan oleh manusia, membuat mereka ingin segera menyelesaikan berbagai aktivitas tersebut seperti berkomunikasi dengan berbagai pihak, pekerjaan yang semakin hari semakin bertambah, transaksi yang harus dilakukan baik yang bersifat penerimaan maupun pengeluaran, membuat manusia mengharapkan adanya kemudahan untuk menyelesaikan semua hal tersebut seiiring dengan berkembangannya teknologi. Masyarakat saat ini telah menyadari pentingnya alat pembayaran yang bersifat non tunai yaitu dengan menggunakan uang elektronik. Uang elektronik atau e-money adalah uang yang memiliki sistem penyimpanan harga digital dan digunakan untuk bertransaksi dengan cara elektronik yang melibatkan jaringan internet (Novitasari, 2016).

Dalam mendukung penggunaan pembayaran non tunai serta menumbuhkan kesadaran di kalangan masyarakat, pelaku bisnis dan lembaga-lembaga pemerintah, maka Bank Indonesia pada tanggal 14 Agustus 2014 menyosialisasikan Gerakan Nasional Non Tunai (GNNT). Gerakan Nasional 
Non Tunai (GNNT) adalah gerakan penggunaan alat pembayaran non tunai yang dicanangkan Bank Indonesia (Nontunai, 2017). Di Indonesia, e-money sudah mulai berkembang dan jumlah penggunanya telah meningkat dari tahun ke tahun. Hal tersebut dapat dibuktikan dengan peningkatan volume dan nilai transaksi e-money yang ada di Indonesia.

Berdasarkan data Bank Indonesia, volume transaksi uang elektronik pada akhir 2018 melonjak menjadi 2,9 miliar transaksi e-money dibandingkan 2017 sebesar 943,3 juta transaksi e-money. Hingga Juli 2019, volume transaksi uang elektronik telah mencapai 2,7 miliar transaksi e-money atau mendekati angka pada akhir 2018. Pada 2018 nilai transaksi uang elektronik mencapai 47,2 triliun rupiah (Jayani, 2019). Peningkatan transaksi uang elektronik sejalan dengan program Gerakan Nasional Non Tunai (GNNT) yang dicanangkan oleh Bank Indonesia sejak tahun 2014. Hingga saat ini terdapat 49 penerbit e-money yang ada di Indonesia. Data Bank Indonesia per April 2020 mencatat, terdiri dari 14 penerbit yang merupakan bank dan 35 penerbit lembaga selain bank.

Penggunaan e-money telah diterapkan pada beberapa universitas di Indonesia untuk transaksi ekonomi yang terjadi di dalam kampus dalam berbagai penggunaan. Tahun 2013 Universitas Indonesia telah menerapkan penggunaan e-money di kantin kampus. Fakultas Ekonomika dan Bisnis Universitas Diponegoro (FEB Undip) juga sudah lama menerapkan e-money yakni Kartu Flazz BCA sebagai kartu mahasiswa dan kartu kepegawaian (Ramadhan dkk, 2016). Hal ini juga terjadi di Politeknik Negeri Semarang, sejak tahun 2019 beberapa mahasiswa di Jurusan Akuntansi telah menggunakan e-money yang diberi nama Polines Pay. Polines Pay merupakan kartu e-money yang dapat digunakan untuk transaksi di kantin Polines dan pembayaran biaya kompensasi. Keberadaan Polines Pay memberikan kemudahan mahasiswa dalam melakukan transaksi berbagai macam transaksi.

Akses kemudahan yang diberikan oleh e-money sangat menarik perhatian para penggunanya hal ini sesuai dengan Penelitian terdahulu yang dilakukan oleh Adiyanti dan Pudjihardjo (2015) menunjukkan bahwa variabel daya tarik promosi berpengaruh positif signifikan terhadap minat dalam menggunakan uang elektronik. Namun berbeda dengan hasil penelitian yang dilakukan Zulqurnain (2017) menunjukkan bahwa variabel daya tarik promosi tidak memiliki pengaruh yang signifikan terhadap minat penggunaan e-money pada mahasiswa UGM. Hasil penelitian yang dilakukan Utami dan Kusumawati (2017) menunjukkan bahwa variabel kemudahan berpengaruh signifikan terhadap minat mahasiswa menggunakan e-money. Hadirnya e-money di kalangan mahasiswa Polines ini menghadirkan banyak manfaat bagi mereka. Namun masih ada kendala yang harus disempurnakan dalam e-money yang dimiliki oleh Polines. Berdasarkan keterangan dari beberapa mahasiswa disebutkan bahwa e-money yang berbentuk aplikasi sangat bergantung pada jaringan dan harus dioperasikan melalui ponsel yang canggih. Untuk e-money yang berbentuk kartu, fasilitas untuk membayar belanja online sudah tidak tersedia lagi. Selain itu, tingkat keamanan juga menjadi perhatian pengguna e-money.

Menurut Firmansyah dan Dacholfany (2018) uang elektronik (atau uang digital) adalah uang yang digunakan dalam transaksi internet dengan cara elektronik. Transaksi ini melibatkan penggunaan jaringan komputer (seperti internet dan sistem penyimpanan harga digital). Electronic Funds Transfer (EFT) adalah sebuah contoh uang elektronik. Secara umum kategori Produk e-money terdiri dari 2 kelompok yaitu card-based product dan software-based product. Adapun Card-Based Product adalah jenis e-money yang menggunakan kartu dengan teknologi Smart Card (kartu pintar). Kartu pintar adalah kartu plastik, dan berisi satu atau lebih chip semikonduktor tertanam. Kartu pintar biasanya memiliki tempat penyimpanan di EEPROM berfungsi sebagai penyimpanan nilai elektronis (saldo) dan juga biasanya tersedia mikroprosesor untuk melakukan proses data untuk saldo e-money (Bonugli P.K, 2006) dalam Firdauzi (2017). Software-Based Product adalah e-money berbasis server yaitu nilai elektronis terletak pada sebuah server yang terhubung melalui suatu jaringan komputer/internet (Departemen Komunikasi, 2020). Dasar Hukum Penyelenggaraan uang elektronik telah diatur dalam Peraturan Bank 
Indonesia Nomor 20/6/PBI/2018 tanggal 4 Mei 2018 tentang Uang Elektronik (Electronic Money) dan Surat Edaran Bank Indonesia No. 11/11/DASP tanggal 13 April 2009 perihal Uang Elektronik (Electronic Money), sehingga para pengguna merasa terjamin ketika melakukan transaksi dengan e-money dan hal ini akan berdampak pada semakin meningkatnya pengguna e-money dikalangan masyarakat umum.

Menurut Schiffman \& Kanuk dalam Shahnaz dan Wahyono (2016) Minat merupakan ketertarikan konsumen terhadap suatu produk dengan mencari informasi tambahan. Minat merupakan salah satu aspek psikis manusia yang dapat mendorong untuk mencapai tujuan. Seseorang yang memiliki minat terhadap suatu obyek, cenderung untuk memberikan perhatian atau merasa senang yang lebih besar kepada obyek tersebut (Kusuma dan Susilowati, 2007). Daya tarik promosi merupakan sebuah kegiatan bukan hanya berfungsi sebagai alat komunikasi antara perusahaan dan konsumen, tetapi juga sebagai alat untuk mempengaruhi konsumen dalam kegiatan pembelian atau penggunaan jasa sesuai dengan keinginan dan kebutuhannya (Zulqurnain, 2017). Promosi merupakan suatu program yang memberi informasi kepada konsumen mengenai keunggulan produk (Kotler dan Amstrong, 2001:153). Kegiatan ini dapat dilakukan perusahaan baik secara langsung, diberbagai cetak seperti reklame atau baliho, majalah, maupun melalui media media elektronik, dalam upaya mempengaruhi konsumen atau menarik minat beli konsumen dalam melakukan keputusan pembelian. Agar konsumen bersedia membeli, maka promosi produk harus mempunyai daya tarik. Minat beli konsumen harus didukung dengan fasilitas yang memungkinkan calon pembeli maupun pembeli sehingga dapat menikmati promosi tersebut. Pendapat yang lain promosi merupakan salah satu variabel dalam bauran pemasaran yang sangat penting dilaksanakan oleh perusahaan dalam memasarkan produk (Sunyoto (2012: 154). Sehingga promosi bukan hanya didengar tetapi juga bisa dilihat dan dirasakan serta menimbulkan daya tarik. Penelitian terdahulu yang dilakukan oleh Adiyanti dan Pudjihardjo (2015) menunjukkan bahwa variabel daya tarik promosi berpengaruh positif signifikan terhadap minat dalam menggunakan uang elektronik. Daya tarik promosi yang bagus dapat mempengaruhi minat seseorang dalam menggunakan produk baru tersebut. Hasil dari penelitian Akmaliyah (2017) menunjukkan bahwa daya tarik promosi memiliki pengaruh positif langsung secara signifikan terhadap minat penggunaan ulang e-money dan arah hubungan promosi dengan minat penggunaan ulang adalah positif.

Persepsi tentang kemudahan penggunaan sebuah teknologi didefinisikan sebagai suatu ukuran seseorang percaya bahwa, komputer dapat dengan mudah dipahami dan digunakan. Jika seseorang merasa percaya bahwa sistem tersebut berguna maka dia akan bereaksi positif terhadap sistem tersebut dan akan menggunakannya. Sebaliknya, jika seseorang merasa percaya bahwa sistem informasi kurang berguna maka dia tidak akan menggunakannya (Istiarni dan Hadiprajitno 2014). Perceive ease of use didefinisikan sebagai "kondisi dimana seorang individu mempercayai bahwa menggunakan suatu teknologi tidak memerlukan upaya fisik dan mental" (Davis, 1993) dalam (Sumarwan dan Tjiptono, 2018). Persepsi kemudahan pengguna menurut Jogiyanto (2009) didefinisikan sebagai sejauh mana seseorang percaya bahwa menggunakan suatu teknologi akan bebas dari usaha. Dari definisinya maka dapat diketahui bahwa persepsi kemudahan merupakan suatu kepercayaan tentang pengambilan keputusan. Jika seseorang merasa percaya bahwa sistem informasi mudah digunakan maka dia akan menggunakan. Davis (1989) dalam Saraswati (2021:16) menyebutkan indikator kemudahan penggunaan teknologi informasi meliputi Easy to Learn (Sistem mudah dipelajari penggunaannya), Controllabe (sistem mudah dijalankan), Clear and Understandable (sistem jelas dan mudah dimengerti), Flexible (fleksibel), Easy to Become Skilful (mudah dan menjadi terampil menggunakan) dan Easy to Use (mudah digunakan). Hasil penelitian dari Utami dan Kusumawati (2017) menunjukkan bahwa variabel kemudahan berpengaruh signifikan terhadap minat mahasiswa dalam menggunakan e-money. Kemudahan penggunaan e-money harus lebih tinggi dibandingkan dengan uang cash karena hakikatnya tujuan dari diterapkannya e-money salah satunya adalah dengan kemudahan atau praktis. Penelitian Ramadhan dkk (2016) memberikan 
hasil bahwa persepsi kemudahan berpengaruh positif dan signifikan terhadap minat mahasiswa untuk menggunakan e-money. Sehingga dapat mempercepat proses penyelesaian masalah, namun tidak cukup dengan itu keamanan juga mencuri perhatian yang cukup besar dalam perkembangan teknologi karena kejahatan digital bisa terjadi kapanpun dan dimanapun.

Menurut G. J. Simons, keamanan sistem informasi adalah bagaimana kita dapat mencegah penipuan (cheating) atau, paling tidak, mendeteksi adanya penipuan di sebuah sistem berbasis informasi, dimana informasinya sendiri tidak memiliki arti fisik (Chazar, 2015). Dalam sebuah artikel disebutkan penggunaan e-Money lebih aman dibandingkan dengan uang tunai, hal ini disebabkan karena catatan pengeluaran dapat dilacak, praktis, dapat diperoleh kembali, keamanan berlapis-lapis, perlindungan bagi traveller, memiliki system melindungi pada saat kartu dicuri atau ilang (Nisaputra, 2017). Keamanan diukur melalui tiga dimensi yaitu credit, reliability, dan privacy (Damghanian et al, 2016). Dimensi tersebut dapat melindungi seluruh data pemilik yang terdapat pada kartu. Hal ini ditunjukkan dari hasil penelitian terdahulu yang menyebutkan adanya pengaruh. Penelitian Ramadhan dkk (2016) memberikan hasil bahwa persepsi keamanan dan risiko berpengaruh positif dan signifikan terhadap minat mahasiswa untuk menggunakan e-money. Dalam penelitian Sari (2019) variabel keamanan berpengaruh positif dan signifikan terhadap sikap penggunaan dalam menggunakan e-money.

Model Technology Acceptance Model (TAM) menawarkan sebuah fondasi untuk mengevaluasi dampak dari variabel-variabel tertentu terhadap beliefs (kepercayaan internal), attitudes (sikap), dan intentions (minat). Teori ini menjelaskan bahwa sikap terhadap penggunaan dan penerimaan teknologi merupakan fungsi dari dua konstruk, yaitu perceived usefulness of technology (persepsi terhadap kegunaan teknologi) dan perceived ease of use of the technology (persepsi terhadap kemudahan teknologi). (Davis et al, 1989) dalam (Sumarwan dan Tjiptono, 2018). Mengingat pentingnya hal tersebut maka peneliti tertarik untuk menganalisa daya tarik promosi, kemudahan dan keamanan dalam mempengaruhi minat menggunakan e-money didukung dengan berbagai penelitian terdahulu antara lain Adiyanti dan Pudjihardjo (2015), Utami dan Kusumastuti (2017).

Berdasarkan hasil pemaparan diatas, maka kerangka pemikiran yang mendasari penelitian ini bertujuan untuk mengetahui pengaruh daya tarik promosi, kemudahan penggunaan, dan keamanan terhadap minat penggunaan e-money pada mahasiswa Politeknik Negeri Semarang. Kerangka pemikiran dapat dilihat pada Gambar 1.

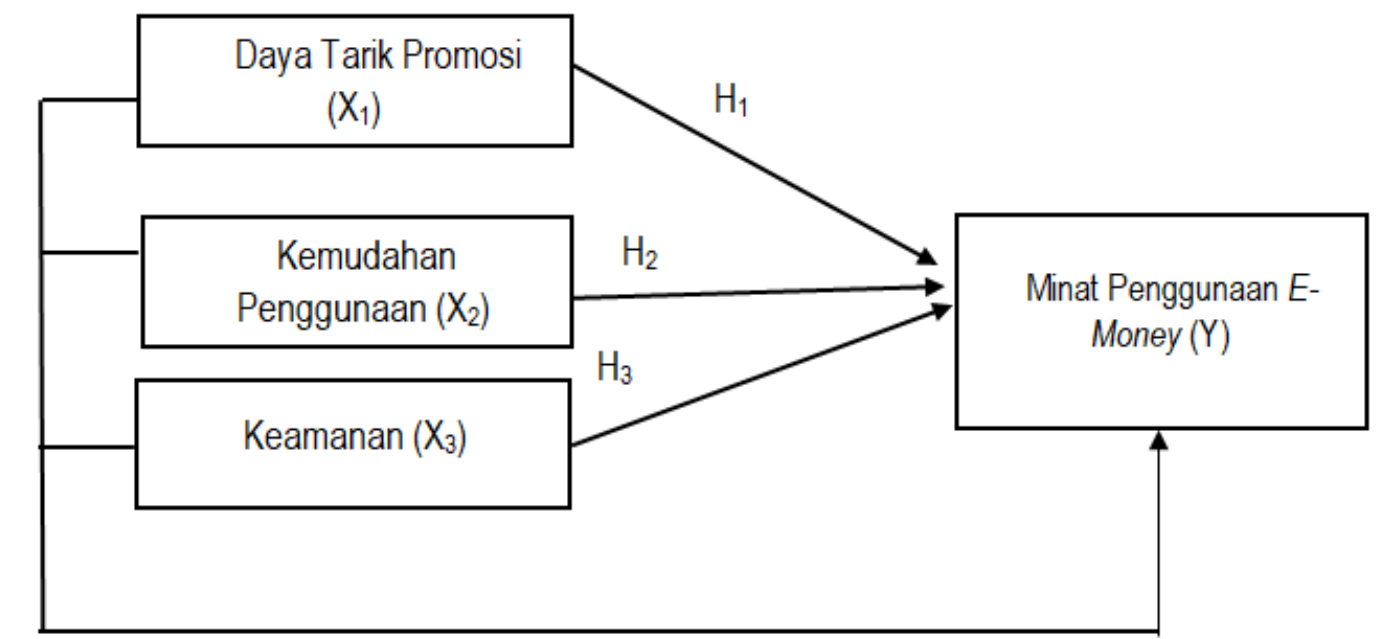

Sumber: Akmaliyah (2017), Adiyanti dan Pudjihardjo (2015), Firdauzi (2017),Utami dan Kusumawati (2017) Ramadhan dkk (2016)

Gambar 1. Kerangka Pemikiran Teoritis 
Berdasarkan kerangka pemikiran diatas maka hipotesis yang diajukan dalam penelitian ini adalah $\mathrm{H}_{1}=$ Daya tarik promosi berpengaruh signifikan terhadap minat penggunaan e-money

$\mathrm{H}_{2}=$ Kemudahan penggunaan berpengaruh signifikan terhadap minat penggunaan e-money

$\mathrm{H}_{3}=$ Keamanan berpengaruh signifikan terhadap minat penggunaan e-money.

Model dalam peneltian ini adalah:

Keterangan :

$$
Y=a+b_{1} X_{1}+b_{2} X_{2}+b_{3} X_{3}+e
$$

$\mathrm{Y} \quad=$ Minat penggunaan e-money.

a $\quad=$ Konstanta.

$\mathrm{b}_{1,2,3}=$ Koefisien regresi untuk masing-masing $X_{1,2,3}$.

$\mathrm{X}_{1,2,3 .}=$ Daya tarik promosi, kemudahan penggunaan, dan keamanan.

$\mathrm{e} \quad=$ Kesalahan residual (error).

\section{METODE PENELITIAN}

Penelitian ini adalah penelitian kausal. Penelitian jenis kausal berguna untuk menganalisis bagaimana suatu variabel mempengaruhi variabel lain (Umar, 2003:105).Populasi dalam penelitian menggambarkan keseluruhan kelompok yang diteliti dan berasal dari orang, kejadian, atau hal lain yang menjadi fokus penelitian (Sumarwan, 2014). Populasi dalam penelitian ini adalah semua mahasiswa Politeknik Negeri Semarang. Sedangkan sampel penelitian adalah sebagian dari jumlah dan karakteristik yang dimiliki oleh populasi tersebut, ataupun bagian kecil dari anggota populasi yang diambil menurut prosedur tertentu sehingga dapat mewakili populasinya (Siyoto dan Sodik, 2015).

Jumlah populasi mahasiswa Politeknik Negeri Semarang adalah 4.916 mahasiswa. Pengambilan sampel menggunakan metode Slovin. Menurut Sujarweni (2015:108) pengambilan sampel tersebut dapat dihitung menggunakan rumus sebagai berikut:

$$
n=\frac{N}{1+N(e)^{2}}
$$

Keterangan:

$\mathrm{n}=$ Ukuran sampel

$\mathrm{N}=$ Ukuran populasi

$e=$ Kesalahan pengambilan sampel sebesar $10 \%$ atau 0,1 .

Berdasarkan rumus diatas sampel yang digunakan dalam penelitian berjumlah 100 mahasiswa dari total populasi mahasiswa Politeknik Negeri Semarang. Pemilihan sampel dalam penelitian ini menggunakan convenience sampling, yakni dipilih sesuai kemudahan. Pengumpulan data menggunakan kuesioner yang disebarkan kepada responden yakni mahasiswa polines sehingga data yang digunakan dalam penelitian ini menggunakan data primer dengan pengukuran menggunkan likert berbobot 1-4 (sangat tidak setuju, tidak setuju, setuju, sangat setuju).

Definisi operasional variabel dalam penelitian ini adalah minat merupakan salah satu aspek psikis manusia yang dapat mendorong untuk mencapai tujuan. Daya tarik promosi merupakan sebuah komunikasi antara perusahaan dan konsumen untuk mempengaruhi konsumen menggunakan jasa sesuai dengan keinginan dan kebutuhannya. Kemudahan penggunaan merupakan sejauh mana seseorang percaya bahwa menggunakan suatu teknologi akan bebas dari usaha. Keamanan pencegahan penipuan pada sebuah sistem berbasis informasi, dimana informasinya sendiri tidak memiliki arti fisik. Seluruh variabel akan dianalisa menggunakan regresi berganda dengan bantuan SPSS 25 (Ghozali, 2018). 


\section{HASIL DAN PEMBAHASAN}

Responden dari penelitian ini terdiri dari 100 mahasiswa yang kuliah di 5 Jurusan yang ada di Politeknik Negeri Semarang. Responden terdiri dari 44 orang (44\%) mahasiswa Laki-Laki dan 56 orang (56\%) mahasiswa Perempuan. Responden dari Jurusan Akuntansi sebanyak 34 orarng (34\%), Jurusan Teknik Elektro sebanyak 20 orang (20\%), Jurusan Teknik Mesin sebanyak 16 orang(16\%), dan dari Jurusan Teknik Sipil sebanyak 10 orang (10\%). Jenis e-money yang digunakan responden yaitu: DANA sebanyak 44 Orang (44\%), OVO ada 22 orang (22\%), Gopay 25 orang (25\%), Brizzi satu orang (1\%), Flazz satu orang (1\%), Mandiri e-money 2 orang (2\%), dan menggunakan Lainnya 5 orang $(5 \%)$ Dari gambaran responden menunjukkan bahwa mayoritas reponden berjenis kelamin perempuan (56\%), responden paling banyak berasal dari Jurusan Akuntansi (34\%), dan jenis e-money yang digunakan paling banyak adalah DANA (44\%).

Hasil Uji validitas menujukkan daya tarik promosi, kemudahan penggunaan, keamanan, dan minat penggunaan e-money pada mahasiswa Politeknik Negeri Semarang memenuhi kriteria valid yakni $r$ hitung $>r$ tabel sehingga dapat dikatakan bahwa seluruh item pertanyaan dapat digunakan. Sedangkan hasil uji reliabilitas seluruh variabel memenuhi kriteria reliabilitas yakni memiliki nilai Cronbach Alpha $>0,70$ sehingga indikator atau kuesioner penelitian dapat dikatakan handal atau reliabel sebagai alat ukur variabel data. Hasil uji asumsi klasik yang terdiri dari uji normalitas, multikolonieritas, dan heteroskedastisitas. Uji normalitas menunjukkan hasil yang normal baik menggunakan metode graphik maupun menggunakan Kolmogorov-Smirnov dengan nilai asymptotic significance 0,166 >0,05. Hasil uji multokolonieritas menunjukkan bahwa hasil perhitungan nilai VIF (Variance Inflation Factor) kurang dari dari 10 dan nilai tolerance lebih dari 0,10 yang berarti bebas problem multikolonieritas. Hasil uji heteroskedastisitas dengan uji Glejser menunjukkan tingkat signifikansi di atas 0,05. Sehingga disimpulkan tidak ada problem heteroskedastisitas.

Pengujian Kelayakan Model dilakukan dengan Uji F. Hal ini dilakukan dengan menguji signifikansi Pengaruh variabel bebas yaitu daya tarik promosi, kemudahan penggunaan, dan keamanan secara bersama-sama terhadap variabel terikat yaitu minat penggunaan e-money menggunakan Uji F. Menurut Ghozali (2018:98) bila $F_{\text {hitung }}>F_{\text {tabel }}$ maka terdapat pengaruh signifikan secara simultan daya tarik, kemudahan penggunaan, dan keamanan terhadap minat penggunaan e-money dan sebaliknya.

\section{Tabel 1. Hasil Uji F}

ANOVA $^{\text {a }}$

\begin{tabular}{|ll|r|r|r|r|c|}
\hline \multicolumn{1}{|c|}{} & \multicolumn{1}{c|}{$\begin{array}{c}\text { Sum of } \\
\text { Sqdel }\end{array}$} & \multicolumn{1}{c|}{ df } & Mean Square & \multicolumn{1}{c|}{ F } & Sig. \\
\hline 1 & Regression & 103.980 & 3 & 34.660 & 45.724 & $.000^{\mathrm{b}}$ \\
& Residual & 72.770 & 96 & .758 & & \\
& Total & 176.750 & 99 & & & \\
\hline
\end{tabular}

a. Dependent Variable: Minat_Penggunaan_emoney

b. Predictors: (Constant), Keamanan, Daya_Tarik_Promosi, Kemudahan_Penggunaan

Sumber: Data primer yang diolah (2020)

Tabel 1 menunjukkan hasil Uji $F$ dengan nilai $F_{\text {hitung }} 45,724>F_{\text {tabel }} 2,70$. Nilai signifikansi menunjukkan hasil 0,000 lebih kecil dari 0,05 sehingga dapat disimpulkan daya tarik promosi, kemudahan penggunaan, dan keamanan mempunyai pengaruh yang bermakna secara simultan terhadap minat penggunaan e-money sehingga model dikatakan layak untuk dijadikan alat prediksi.

Pengujian kemampuan model dalam menerangkan variasi variabel independen terhadap variabel dependen dilakukan dengan Uji Koefisien Determinasi. Koefisien determinasi (adjusted $\mathrm{R}^{2}$ ) dinyatakan 
dalam persentase. Nilai koefisien determinasi adalah antara nol dan satu atau $0<R^{2}<1$ (Ghozali, 2018: 97). Adapun hasil uji koefisien determinasi dapat dilihat pada Tabel 2.

Tabel 2. Hasil Uji Koefisien Determinasi Model Summary

\begin{tabular}{|l|l|l|r|r|}
\hline Model & $\mathrm{R}$ & R Square & $\begin{array}{c}\text { Adjusted R } \\
\text { Square }\end{array}$ & $\begin{array}{c}\text { Std. Error of } \\
\text { the Estimate }\end{array}$ \\
\hline 1 & $.767^{\mathrm{a}}$ & .588 & .575 & .871 \\
\hline
\end{tabular}

a. Predictors: (Constant), Keamanan, Daya_Tarik_Promosi, Kemudahan_Penggunaan

b. Dependent Variable: Minat_Penggunaan_emoney

Sumber: Data primer yang diolah (2020)

Berdasar Tabel 2 diketahui bahwa nilai koefisien determinasi terdapat pada nilai Adjusted $R$ Square sebesar 0.575 . Hal ini menunjukkan bahwa kemampuan variabel daya tarik promosi, kemudahan dan keamanan dalam mempengaruhi variasi variabel terikat sebesar $57.50 \%$ dan sisanya sebesar $42.50 \%$ dipengaruhi oleh variabel lain yang tidak diteliti dalam penelitian ini seperti kepercayaan, antara lain kualitas Layanan, Trust, Norma subjektif, Persepsi control.

Hasil uji $t$ menunjukkan nilai $t$ nitung Variabel Daya Tarik Promosi sebesar 2.268, Variabel Kemudahan Penggunaan diketahui $t$ hitung sebesar 5.018, dan Variabel Keamanan diketahui $t$ hitung sebesar 3.973. Sedangkan nilai signifikansi untuk variabel Daya Tarik Promosi sebesar 0.026, Nilai signifikansi untuk variabel Kemudahan sebesar 0.00 dan nilai signifikansi untuk variabel Keamanan 0.00 . Hal ini menunjukkan seluruh hipotesis yang diajukan $(\mathrm{H} 1, \mathrm{H} 2$ dan $\mathrm{H} 3)$ dalam penelitian ini semuaya diterima.

Tabel 3 Hasil Uji t

\begin{tabular}{|c|c|c|c|c|c|c|}
\hline \multirow{2}{*}{\multicolumn{2}{|c|}{ Model }} & \multicolumn{2}{|c|}{$\begin{array}{l}\text { Unstandardized } \\
\text { Coefficients }\end{array}$} & \multirow{2}{*}{ 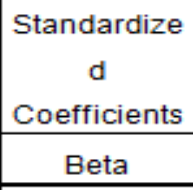 } & \multirow[t]{2}{*}{$\mathrm{t}$} & \multirow[t]{2}{*}{ Sig. } \\
\hline & & $\mathrm{B}$ & Std. Error & & & \\
\hline \multirow{4}{*}{1} & (Constant) & .578 & .853 & & .678 & .500 \\
\hline & Daya_Tarik_Promosi & .188 & .083 & .199 & 2.268 & .026 \\
\hline & $\begin{array}{l}\text { Kemudahan_Penggu } \\
\text { naan }\end{array}$ & .378 & .075 & .444 & 5.018 & .000 \\
\hline & Keamanan & .249 & .063 & .291 & 3.973 & .000 \\
\hline
\end{tabular}

a. Dependent Variable: Minat_Penggunaan_emoney

Sumber: Data primer yang diolah (2020)

Tabel 3 menunjukkan hasil analisis model regresi linier berganda, uji t dan hasil nilai signifikansi dari Variabel Daya Tarik Promosi, Kemudahan Penggunaan dan Keamanan. Hasil analisis model regresi menunjukkan bahwa nilai konstanta (a) dari model regresi adalah 0,578 dan koefisien regresi (b) dari masing masing variabel independen adalah $b_{1}=0,188, b_{2}=0,378$, dan $b_{3}=0,249$. Dengan demikian model persamaan regresi linier berganda penelitian:

$$
Y=0,578+0,188 X_{1}+0,378 X_{2}+0,249 X_{3}+e
$$

Nilai konstanta 0.578 , menunjukkan bila daya tarik promosi, kemudahan penggunaan, dan keamanan mengalami perubahan maka minat penggunaan e-money pada mahasiswa Politeknik Negeri Semarang akan berubah sebesar 0,578 . Daya tarik promosi terhadap minat penggunaan e-money menunjukkan pengaruh signifikan. Tehnik promosi dalam mengenalkan sesuatu yang baru menjadi pemicu untuk lebih mengetahui suatu produk sehingga menjadikan produk tersebut menarik, selain itu 
promosi harus dikelola dengan strategi yang tepat. Menurut Swastha (2000) dalam (Utami dan Kusumawati, 2017) untuk membeli produk diperlukan minat. Minat dalam memutukan memilih suatu produk dilihat dari kebermanfaatan yang dirasakan ketika membeli produk tersebut. Bila kebermanfaat yang diterima semakin besar sperti cukup dengan membawa satu kartu semua masalah teratasi, maka minat untuk memiliki semakin tinggi sehingga keinginan untuk membeli akan semakin besar. Hasil penelitian sama seperti hasil penelitian Adiyanti dan Pudjihardjo (2015) dan Akmaliyah (2017). Untuk meningkatkan Daya tarik promosi adalah dengan penyampaian pesan-pesan penjualan yang diarahkan kepada masyarakat melalui cara-cara persuasif yang bertujuan menjual barang, jasa atau ide (Bachriansyah, 2011).

Kemudahan penggunaan terhadap minat penggunaan e-money menunjukkan pengaruh signifikan. Seseorang yang bereaksi positif terhadap sesuatu yang baru akan membuka diri untuk lebih mengenal bahkan mencari tahu sistem yang digunakan dan mencobanya (Istiarni dan Hadiprajitno, 2014). Seseorang yang telah mencoba dapat mengetahui kesulitan dan kemudahan sistem yang telah berjalan. Kemudahan akses dalam penggunaan lebih menarik, hal ini dikarenakan sudah terlalu banyak kerumitan yang telah ditemui dalam berbagai hal sehingga bila ada yang mudah penggunaanya akan lebih diminati karena akan mempermudah pekerjaannya tanpa harus ribet membawa uang dalam jumlah banyak cukup dengan satu kartu digenggaman semua kebutuhan transaksi dapat terselesaikan. Hasil penelitian sama seperti hasil penelitian Firdauzi (2017). Kemudahan penggunaan tidak hanya dalam hal mengoperasikan e-money tetapi juga dalam hal memudahkan interaksi individu terhadap kebutuhannya. Venkatesh dan Davis (2000: 201) membagi dimensi persepsi kemudahan penggunaan menjadi interaksi individu dengan sistem jelas dan mudah dimengerti (clear and understandable), tidak dibutuhkan banyak usaha untuk berinteraksi dengan sistem tersebut (does not require a lot of mental effort), sistem mudah digunakan (easy to use), dan mudah mengoperasikan sistem sesuai dengan apa yang ingin individu kerjakan (easy to get the system to do what he/she wants to do). Kemudahan penggunaan sebuah sistem akan mempercepat penyelesaian sebuah proses, sehingga memudahkan mahasiswa politeknik negeri semarang dalam melakukan berbagai transaksi.

Kemanan terhadap minat penggunaan e-money menunjukkan pengaruh yang signifikan. Menurut G. J. Simons, keamanan sistem informasi adalah bagaimana kita dapat mencegah penipuan (cheating) atau, paling tidak, mendeteksi adanya penipuan di sebuah sistem berbasis informasi, dimana informasinya sendiri tidak memiliki arti fisik" (Chazar, 2015). Hasil penelitian Sathye dalam Almuntaha (2008) menyatakan bahwa Keamanan merupakan isu yang paling penting, hal ini dikarenakan banyak data yang bersifat rahasia dan harus dilindungi dengan tingkat keamanaan yang terjamin. Tingkat kemananan data yang terdapat dalam e-money dapat menghindari manipulasi data, menghindari pencurian data pribadi dan saldo nominal. Hasil penelitian ini didukung oleh penelitian Sari (2019) membuktikan bahwa keamanan berpengaruh positif dan signifikan terhadap minat penggunaan e-money. Tingkat

Promosi yang dapat menjadikan daya tarik, kemudahan penggunaan yang diberikan kepada konsumen serta keamanan yang terjamin membutuhkan aplikasi teknologi yang mendukung sebagai upaya menjadikan konsumen terutama generasi milenial seperti mahasiswa minat menggunakan emoney yang dapat dipercaya. Perkembangan teknologi dikatakan berhasil apabila dapat meningkatkan pelayanan untuk penggunanya. Apabila user (pengguna) semakin banyak menggunakan teknologi tersebut maka minat seseorang menjadi faktor penting dalam penggunaan teknologi (Ahmad dan Bambang, 2014). Hasil penelitian Dzulhaida, dkk (2015) menyebutkan faktor yang paling besar dalam mempengaruhi minat masyarakat untuk menggunakan layanan e-money adalah kepercayaan yang dirasakan oleh masyarakat terhadap layanan e-money (Perceived Trust). Faktor yang dapat mempengaruhi minat masyarakat untuk menggunakan layanan e-money di Indonesia yaitu variabel 
Performance Expectancy (PE), Effort expectancy (EE) dan variabel Social Influence (SI), dengan adanya hal tersebut diharapkan dapat meningkatkan minat masyarakat untuk menggunakan e-money.

\section{PENUTUP}

Berdasarkan uji regresi yang telah dilakukan dalam penelitian ini, hasilnya secara parsial menunjukkan daya tarik promosi berpengaruh signifikan terhadap minat penggunaan e-money pada mahasiswa politeknik negeri semarang dengan nilai koefisien sebesar 0,188 . Kemudahan pengguna berpengaruh signifikan terhadap minat penggunaan e-money pada mahasiswa politeknik negeri semarang dengan nilai koefisien sebesar 0,0378 serta keamanan berpengaruh signifikan terhadap minat penggunaan e-money pada mahasiswa politeknik negeri semarang dengan nilai koefisien sebesar 0,249. Secara simultan menunjukkan seluruh variabel antara lain daya tarik promosi, kemudahan penggunaan, dan keamanan memberikan kontribusi pengaruh terhadap minat penggunaan e-money pada mahasiswa politeknik negeri semarang sebesar $57,50 \%$. Sedangkan sisanya sebesar $42,50 \%$ dipengaruhi oleh variabel lain yang tidak diteliti dalam penelitian ini. Semakin baik strategi promosi yang dilakukan untuk menarik mahasiswa politeknik negeri semarang dengan kemudahan penggunaan dan tingkat keamanan yang tinggi maka semakin besar minat mahasiswa Politeknik Negeri Semarang untuk dapat memiliki emoney sehingga memberikan kemudahan dan praktis dalam melakukan transaksi yang diperlukan. Penelitian ini terbatas pada daya tarik promosi, kemudahan penggunaan, keamanan serta minat penggunaan e-money pada Mahasiswa Politeknik Negeri Semarang. pada penelitian selanjutnya diharapkan focus pada salah satu produk e-money, menambahkan variabel lain seperti Trust, WOM, Kualitas Layanan, Kepuasan dan Kepercayaan responden dalam penggunaan e-money serta memperluas sampel penelitian tidak hanya pada satu kampus namun melibatkan banyak kampus sehingga dapat lebih komprehensif Penelitian .

\section{DAFTAR PUSTAKA:}

Adiyanti, A. I. dan Pudjihardjo, M. 2015. Pengaruh Pendapatan, Manfaat, Kemudahan Penggunaan, Daya Tarik Promosi, Dan Kepercayaan Terhadap Minat Menggunakan Layanan E-Money. Jurnal IImiah Mahasiswa FEB Universitas Brawijaya, 3(1).

Ahmad. dan Bambang S.P. 2014. Pengaruh Persepsi Manfaat, Persepsi Kemudahan, Keamanan, dan Ketersediaan Fitur terhadap Minat Ulang Nasabah Bank dalam Menggunakan Internet Banking pada Program Layanan Internet Banking BRI. Jurnal Studi Manajemen, 8(1), 1-11.

Akmaliyah, D. 2017. Faktor-Faktor yang Mempengaruhi Minat Pembelian Ulang Kartu E-Money Bank Mandiri. Skripsi. Bogor: Institut Pertanian Bogor.

Almuntaha, E. 2008. Faktor-Faktor yang Mempengaruhi Pengadopsian Teknologi Internet Banking oleh Nasabah di Indonesia. Skripsi. Yogyakarta: Universitas Islam Indonesia.

Bachriansyah, R.A. 2011. Analisis Pengaruh Kualitas Produk, Daya Tarik Iklan, dan Persepsi Harga Terhadap Minat Beli Konsumen Pada Produk Ponsel Nokia (Studi Kasus pada Masyarakat di Kota Semarang). Skripsi. Semarang: Universitas Diponegoro.

Chazar, C. 2015. Standar Manajemen Keamanan Sistem Informasi Berbasis Iso/lec 27001:2005. Jurnal Informasi, 7(2), 48-57.

Damghanian, H., Zarei, A. dan Kojuri, M.A.S. 2016. Impact of Perceived Security on Trust, Perceived Risk, and Acceptance of Online Banking in Iran. Journal of Internet Commerce, 15(3), 214 - 238.

Departemen Komunikasi. 2020. Apa itu Uang Elektronik. Bank Indonesia Edukasi. https://www.bi.go.id/id/edukasi/Pages/Apa-itu-Uang-Elektronik.aspx. diakses tanggal 20 maret 2020 pkl. 10.00 WIB. 
Dzulhaida, R., Rifaldi, R. dan Giri, W. 2015. Analisis Minat Masyarakat terhadap Penggunaan Layanan E-Money Di Indonesia Dengan Menggunakan Model Modifikasi Unified Theory of Acceptance and Use Technology 2 (Utaut 2). Majalah IImiah UNIKOM, 15 (2), 155-166.

Firdauzi, I. 2017. Pengaruh Kemampuan Finansial, Kemudahan, dan Perilaku Konsumen terhadap Minat Penggunaan Uang Elektronik di Kota Yogyakarta. Jurnal Pendidikan dan Ekonomi, 6 (1), 77-87.

Firmansyah, dan Dacholfany, I. 2018. Uang Elektronik dalam Persepektif Islam. Lampung: CV. IQRO.

Ghozali, I. 2018. Aplikasi Analisis Multivariate dengan Program IBM SPSS 25 Edisi 9. Semarang: Badan Penerbit Universitas Diponegoro.

Istiarni, P.R.D., dan Hadiprajitno, P.B. 2014. Analisis pengaruh Persepsi Manfaat, Kemudahan Penggunaan dan Kredibilitas terhadap Minat Penggunaan Berulang Internet Banking dengan Sikap Penggunaan sebagai Variabel Intervening (Studi Empiris: Nasabah Layanan Internet Banking di Indonesia). Diponegoro Journal of Accounting, 3 (2), 1-10.

Jogiyanto, H.M. 2009. Sistem Informasi Keperilakuan. Yogyakarta: Andi.

Jayani, D., H. 2019. Transaksi Uang Elektronik Melonjak 209,8\% pada 2018. Databoks. https://databoks.katadata.co.id/datapublish/2019/09/23/transaksi-uang-elektronik-melonjak-2098-pada2018 diakses tanggal 20 maret 2020 pukul. 10.00 WIB

Kotler, P. Amstrong, G. 2001. Prinsip- prinsip Pemasaran Jilid 1, Prentice Hall Inc, Englewood Clifts, New Jersey: Erlangga.

Kusuma, H. dan Susilowati, D. 2007. Determinan Pengadopsian Layanan Internet Banking Perspektif Konsumen Perbankan Daerah Istimewa Yogyakarta. Jurnal Akuntansi dan Auditing Indonesia, 11 (2), 125-139.

Nisaputra, R. 2017. 6 Alasan e-Money Lebih Aman Dibanding Uang Tunai. Info Bank News. https://infobanknews.com/etalase/tips-and-trick/6-alasan-e-money-lebih-aman-dibanding-uang-tunai/ diakses tanggal 20 maret 2020 pukul. 10.00 WIB.

Novitasari, I. 2016. Pengaruh Kecocokan, Persepsi Kegunaan, Persepsi Kemudahan dan Persepsi Kenyamanan terhadap Minat Penggunaan E-money. Jurnal IImiah Mahasiswa FEB Universitas Brawijaya, 3(2).

Nontunai. 2017. Mengenal Gerakan Nasional Non Tunai. Nontunai. www.nontunai.com/kenali/mengenalgnnt/ diakses pada tanggal 2 Maret 2020 pukul.10.00 WIB

Peraturan Bank Indonesia Nomor 20/6/PBI/2018 tanggal 4 Mei 2018 tentang Uang Elektronik (Electronic Money).

Ramadhan, A. F., Prasetyo, A.B., dan Irvana, L. 2016. Persepsi Mahasiswa dalam Menggunakan EMoney. Jurnal Dinamika Ekonomi dan Bisnis, 3(2), 131-145.

Surat Edaran Bank Indonesia No. 11/11/DASP tanggal 13 April 2009 perihal Uang Elektronik (Electronic Money).

Saraswati, A.N. 2021. Pengaruh Persepsi Kemudahan dan Persepsi Keamanan Terhadap Minat Penggunaan E-Money di Kalangan Generasi Millenial (Studi pada Masyarakat Kecamatan Medan Baru). Skripsi. Medan: Universitas Sumatera Utara.

Sari. I. 2019. Pengaruh Kemudahan, Manfaat Penggunaan Teknologi, Fitur Layanan Dan Keamanan, Terhadap Minat Menggunakan E- Money, Dengan Sikap Penggunaan Sebagai Variabel Intervening. Skripsi: IAIN Salatiga.

Shahnaz, N.B.F., dan Wahyono. (2016). Faktor yang Mempengaruhi Minat Beli di Toko Online. Managemant Analysis Journal, 5(4), 389-399.

Sujarweni, V.W. 2015. Metodologi Penelitian Bisnis \& Ekonomi. Yogyakarta: Pustaka Baru Press.

Sumarwan, U. dan Tjiptono, F. 2018. Strategi Pemasaran dalam Perspektif Perilaku Konsumen. Bogor: IPB Press. 
Sumarwan, U. 2014. Perilaku Konsumen Teori dan Penerapannya dalam Pemasaran. Bogor: Ghalia Indonesia.

Sunyoto, D. 2012. Metodologi Penelitian Akuntansi. Bandung: Refika Aditama.

Siyoto, S. dan Ali, S. 2015. Dasar Metodologi Penelitian.Yogyakarta: Literasi Media Publishing.

Utami, S.S., dan Kusumawati, B. 2017. Faktor-Faktor Yang Memengaruhi Minat Penggunaan E-Money (Studi Pada Mahasiswa STIE Ahmad Dahlan Jakarta). Balance Economic Business, Management and Accounting Journal, 14(2), 29-41.

Umar, H. 2003. Metode Riset Perilaku Konsumen Jasa. Jakarta: Ghalia.

Venkatesh, V., dan Davis, F.D. 2000. A Theoretical Extension of the Technology Aceptance Model: Four Longitudinal Field Studies. Management Sciences, 46(2), 186-204.

Zulqurnain, S. 2017. Pengaruh Daya Tarik Promosi, Persepsi Kemudahan, dan Persepsi Kemanfaatan Terhadap Minat Menggunakan E-Money (Studi Pada Mahasiswa Universitas Gadjah Mada). Skripsi. Yogyakarta: UIN Sunan Kalijaga. 